TEME, г. XLIII, бр. 3, јул - септембар 2019, стр. 783-806

Прегледни рад

Примљено: 10. 6. 2019.

https://doi.org/10.22190/TEME190610048A

Ревидирана верзија: 9. 9. 2019.

Одобрено за штампу: 20. 10. 2019.

\title{
УТИЦАЈ ТЕМПЕРАТУРЕ, ПАДАВИНА И ВЛАЖНОСТИ ВАЗДУХА НА ШТЕТЕ ОД ЕЛЕМЕНТАРНИХ НЕПОГОДА У ДРЖАВНИМ ШУМАМА РЕПУБЛИКЕ СРБИЈЕ
}

\author{
Данијела Аврамовић*, Драган Спасић \\ Универзитет у Нишу, Факултет заштите на раду, Ниш, Србија \\ danijela.avramovic@znrfak.ni.ac.rs
}

\begin{abstract}
Апстракт
Климатске промене су у другој половини 20. века постале глобални проблем чије су последице све израженије. Негативни ефекти климатских промена у облику елементарних непогода највидљивији су на шумским састојинама и екосистемима. Истраживање о последицама неких климатских елемената на шумске састојине Републике Србије обухвата период од 2008. до 2017. године. За потребе истраживања подаци су преузети из званичних статистичких извештаја. Током истраживања прикупљни су и обрађени подаци о: средњој годишњој температури ваздуха, средњој годишњој суми падавина и средњој годишњој релативној влажности ваздуха; броју случајева настале штете и обиму штете у државним шумама од елементарних непогода (инсеката, биљних болести, природних непогода и пожара). Циљ овог рада је да на основу приказаних података и анализе добијених резултата утврди утицај посматраних климатских елемената на број случајева појава, обим настале штете и на штете по једном насталом случају од елементарних непогода у државним шумама Републике Србије. Значај овог рада је тај што он представља пионирски покушај да се на једном месту сагледају утицаји температуре, падавина и влажности ваздуха на број појава и обим штете у државним шумама од инсеката, биљних болести, природних непогода и пожара (елементарних непогода) на територији Републике Србије (без Аутономне Покрајине Косово и Метохија). У раду је утврђена нелинеарна зависност утицаја климатских фактора на број и обим настале штете.
\end{abstract}

Кључне речи: температура, падавине, влажност ваздуха, штете, шуме.

\section{INFLUENCE OF TEMPERATURE, PRECIPITATION AND AIR HUMIDITY ON THE DAMAGE FROM NATURAL HAZARDS AND DISASTERS IN SERBIAN STATE FORESTS}

\footnotetext{
Abstract

Climate change has acquired a status of a global issue in the second half of the 20th century, nowadays becoming more and more prominent. The negative effects of climate
} 
change as manifested through natural disasters are noticeable the most in forest stands and forest ecosystems. This study covers the period from 2008 to 2017, and the data included was collected from official statistical reports. The data on the following categories was collected: average annual air temperature, average annual precipitation, average annual relative air humidity, the number of disaster events, such as insect activity, plant diseases, wildfires, or climate and geological disasters, causing damage in state forests, and the scope of such damage. The aim of this paper is to analyze the said data and to use the results to determine the influence of observed climatic elements on the incidence of damage, the scope of damage, and the damage per one disaster event in Serbian state forests. This paper is significant because it represents a pioneering attempt to synthesize the influence of temperature, precipitation, and humidity on the incidence and scope of damage in state forests resulting from insect activity, plant diseases, geophysical events, and wildfires in Serbia (excluding the Autonomous Province of Kosovo and Metohija). A non-linear dependence of the influence of climate factors on damage incidence and scope has been determined.

Key words: $\quad$ temperature, precipitation, humidity, damage, forests.

\section{УВОД}

Република Србија налази се у централном делу Балканског полуострва и простире се на $88.499 \mathrm{~km}^{2}$ (Републички завод за статистику, 2018a, стр. 14). Укупна површина под шумама и шумским земљиштем у Републици Србији утврђена је на основу Националне инвентуре шума (Драговић, 2017, стр. 16). Према најновијим подацима (2018а, стр. 204 и 228), укупна површина под шумама и шумским земљиштем износи 2.237.511 ha. Од укупне површине под шумама Републике Србије без Аутономне Покрајине Косово и Метохиja, државном сектору припада 963.458 ha (43\%), док преостала површина 1.274 .053 ha (57\%) припада приватном сектору.

Појам елементарне непогоде често се у пракси поистовећује са појмом природне непогоде. Оба појма се у зависности од истраживане проблематике дефинишу на више начина. Према методологији Републичког завода за статистику, за потребе вођења стастичких база података под елементарним непогодама подразумевају се ветар, киша, град, снег и мраз, док, према Закону о смањењу ризика од катастрофа и управљању ванредним ситуаиијама, члан 2 каже:

„Елементарна непогода је појава хидролошког, метеоролошког, геолошког или биолошког порекла, проузрокована деловањем природних сила као што су земљотрес, поплава, бујица, олуја, јака киша, атмосферска пражњења, град, суша, одроњавања или клизања земљишта, снежни наноси и лавина, екстремне температуре ваздуха, нагомилавања леда на водотоку, пандемија, епидемија заразних болести, епидемија сточних заразних болести и појава штеточина и друге природне појаве већих размера које могу да угрозе безбедност, живот и здравље већег броја људи, материјална и културна добра или животну средину у већем обиму" (2018б). 
Природна непогода у шумама, у смислу члана 45 Закона о иумама:

„представља значајан поремећај биолошке равнотеже и настанак озбиљних штета у шумским екосистемима изазваних пре свега пожарима, сушењем, биљним болестима и штеточинама, ветроломима и ветроизвалама, снеголомима и снегоизвалама, поплавама, бујичним токовима, клизиштима и другим непредвиђеним чиниоцима на великим површинама шума и шумског земљишта" (2010).

Последњих година штете у шумама које проузрокују елементарне непогоде, као што су: јак ветар, град, снег, поплаве, клизишта, ниске и високе температуре, пожари, најезде инсеката и појава биљних болести у шумама разликују се из године у годину (Караџић, 2007; Ранковић и др., 2016; Милутиновић, 2018). Према статистичким подацима објављеним у Билтену шумарство у Републищи Србији, а који се односе само на државне шуме током 2015. и 2016. године, инсекти су проузроковали штету на $73.200 \mathrm{~m}^{3}$ дрвне масе (Републички завод за статистику, 2008-2017a, стр. 62). Биљне болести у 2016. години проузроковале су штету на $37.249 \mathrm{~m}^{3}$ дрвне масе (Републички завод за статистику, 2008-2017а, стр. 63). Штете од инсеката и биљних болести варирају у току године у зависности од годишњег доба и колебања одређених климатских елемената (Караџић, 2007, стр. 153; Драговић, 2017, стр. 233, Милутиновић, 2018, стр. 174). Елементарне непогоде (лед и ледоизвале) током зиме 2014. и 2015. године проузроковале су штету која је износила $203.257 \mathrm{~m}^{3}$ дрвне масе (Републички завод за статистику, 2008-2017а, стр. 61 и 63). Што се тиче штете у шумама проузроковане пожарима, током 2012. и 2016. године забележено је око 312 пожара, при чему је оштећено око $66.977 \mathrm{~m}^{3}$ дрвне масе (Републички завод за статистику, 2008-2017а, стр. 61 и 63).

С обзиром на претходно изнете чињенице, а у циљу адекватног приказа доступних статистичких података који су у вези са предметом рада, за потребе овог истраживања под појмом елементарна непогода објединићемо податке који се у статистичком годишњаку Републике Србије систематизују као штете од инсеката, биљних болести, елементарних непогода и пожара. Како би се превазишао проблем појаве појма елементарна непогода у два контекста, извршена је супституција „статистичког појма” штете од елементарних непогода појмом штете од природних непогода. Ови штетни фактори уједно представљају и индикаторе стања штете у шумама који су одређени Правилником о националној листи индикатора заштите животне средине (Службени гласник Р. Србије, бр. 37/2011, стр. 81) ради системског праћења штете у државним шумама Републике Сpбије. 
Учесталост дешавања и обим настале штете у шумским састојинама се последњих година доводе у везу са климатским променама (Kirilenko \& Sedjo, 2007), односно са променама температуре ваздуха, количином падавина (Klein \& Können, 2003; Ранковић, Недељковић, Златић, Станишић \& Нонић, 2016) и влажности ваздуха. У стручној и научној литератури још увек не постоје комплексна истраживања која говоре о утицају ових климатских елемената на учесталост појава и обим настале штете. Најчешће су вршена истраживања појединачних фактора угрожавања, као што су, на пример, штете: од инсеката (Volnej \& Feming, 2000), од биљних болести (Караџић, 2007; Hepting, 2013), од природних непогода (Ранковић и сар. 2016) и од пожара (Живановић, Вукин \& Кењевац, 2019; Живановић, Ђорђевић \& Радаковић, 2012; Петровић, Грујовић, 2015).

Због актуелности ове проблематике, намеће се потреба за покретањем комплексних, тј. Мултидисциплинарних, истраживања у области сагледавања утицаја одређених климатских елемената на појаву броја случајева одређених фактора угрожавања и на обим штете настале њиховим утицајем. Овај рад представља прелиминарно истраживање, које би требало да утврди да ли постоји утицај средњих годишњих вредности истраживаних климатских елемената на појаву броја случајева, обим настале штете и штете по једном случају у државним шумама Републике Србије у периоду од 2008. до 2017. године.

Истраживање је спроведено у три фазе: у првој фази извршено је прикупљање публикованих статистичких података у периоду од 2008. до 2017. године, који се односе на број случајева настале штете и обим штете од елементарних непогода у државним шумама Републике Србије и преузимање и израчунавање средње годишње температуре ваздуха, суму падавина и релативне влажности ваздуха за посматрани период. Друга фаза истраживања обухвата обраду, анализу и дискусију прикупљених статистичких података. Трећу фазу чине закључци са предлогом мера у циљу решавања уочених проблема.

Циљ истраживања је да на основу анализе постојећих статистичких података за десетогодишњи период и добијених резултата утврди да ли постоји утицај средње годишње температуре ваздуха, суме падавина и релативне влажности ваздуха на број случајева насталих штета, обим штете и штете настале по једном случају у државним шумама од елементарних непогода у Републици Србији.

\section{МАТЕРИЈАЛ И МЕТОДЕ РАДА}

Истраживање се заснива на основним аналитичким и синтетичким научним методама (Шешић, 1978). Осим наведених, од класичних метода коришћене су још: индукција и дедукција, генерали- 
зација и специјализација, класификација итд. Подаци о истраживаним појавама приказани су у облику временских серија, што је утицало да се од статистичких метода користи анализа временских серија (Ковачић, 1995; Petz, 2007). За прорачун и анализу података коришћени су софтвери унакрсних табела и бесплатан статистички програм Gretl.

Подаци о температури ваздуха $(T)$, суми падавина (П) и релативној влажности ваздуха ( $p)$ за Републику Србији у периоду од 2008. до 2017. године (Табела 1) преузети су са сајта Републичког хидрометеоролошког завода, који се објављују једном годишње у билтену „Метеоролошки годишњак 1. - Климатолошки подаци” (Републички завод за статистику, 2008-2017б). Приликом преузимања података, уочен је различит број мерних метеоролошких станица по годинама посматрања; у 2008. години мерења су вршена на 41 метеоролошкој станици, године 2009. и 2017. на 40 мерних станица, док су у периоду 2010-2012. и 2015-2016. мерења вршена на 39 метеоролошких станица и у периоду 2013-2014. на 38 метеоролошких станица.

Како би се добиле средње годишње вредности истраживаних климатских елемената за територију Републике Србије, прибегло се израчунавању аритметичке средине измерених вредности на доступним метеоролошким станицама за сваку посматрану годину, према формули:

$$
\bar{x}=\frac{x_{1}+x_{2}+x_{3}+\ldots+x_{n}}{n},
$$

где $\bar{x}$ означава аритметичку средину, $x_{1}+x_{2}+x_{3}+\ldots+x_{n}$ јесу измерене вредности од прве до последње, а $n$ представља број резултата.

У складу са важећом законском регулативом која се односи на шуме, шумарска газдинстава на територији Републике Србије у обавези су да евидентирају све промене у току године на шумским екосистемима, односно штете у државним шумама и редовно шаљу извештаје ресорном министарству (Закон о шумама, члан 67 и 68, 2010; Правилник о националној листи индикатора заштите животне средине - 8.46. Штете у шумама, 2011). Шумарска газдинства такође су у обавези да доставе податке Републичком заводу за статистику о штетама које су проузроковане од стране човека, инсеката, дивљачи и домаћих животиња, елементарних непогода, биљних болести и пожара једном годишње или на две године (Републички завод за статистику, 2008-2017a-5.1. Штете у државним шума).

У делу рада Резултати и дискусија биће анализирани статистички подаци који се односе на штете у шумама од инсеката, биљних болести, природних непогода и пожара које су систематизоване и груписане у складу са Законом о смањењу ризика од катастрофа 
и управљању ванредним ситуацијама као елементарне непогоде (2018б). У оквиру методолошких објашњења у Билтену шумарство y Републици Србији за штете у шумама објављени подаци изражени су у дрвној запремини која се због настале штете морала посећи (Републички завод за статистику, 2008-2017a). Укупне штете у државним шумама Републике Србије (без података за Аутономну Покрајину Косово и Метохија од 1999. године) исказују се као посечена запремина дрвета $\mathrm{m}^{3}$ (Табела 2).

На основу података о укупним штетама у државним шумама у Републици Србији који су прикупљени за период од 2008. до 2017. године и података о штетама од елементарних непогода за исти временски период израчунато је учешће штете [у \%] од елементарних непогода у укупним штетама у државним шумама за сваку посматрану годину (Табела 3), према формули:

$$
[\%]=\frac{\check{S} E N_{i}}{\check{S} D \check{S}_{i}} \cdot 100 \%,
$$

где је: [\%] - учешће штете; $\check{\boldsymbol{S}} \boldsymbol{E} \boldsymbol{N}_{\boldsymbol{i}}$ - укупна штета од елементарних непогода у државним шумама у Републици Србији у анализираној

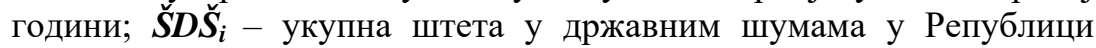
Србији у анализираној години.

Анализом прикупљених података у циљу добијања релевантних резултата у раду су примењене статистичке формуле за израчунавање аритметичке средине појединачног и укупног броја случајева, појединачне штете и укупне штете од елементарних непогода. Затим, одређен је минималан и максималан број случајева настале штете, обим штете и штете по једном насталом случају од елементарних непогода у државним шумама Србије, те њихово средње квадратно одступање од средње вредности (стандардна девијација $-s$ ).

Минималане и максималне вредности одређене су рангирањем од најмање до највеће вредности, наког чега се приступило издвајању прве (минималне) и последње (максималне) вредности.

За статистичко закључивање коришћена је стандардна девијација Студентове расподеле $(s)$, која се израчунава према формули:

$$
s=\sqrt{\frac{\left(\bar{x}-x_{1}\right)^{2}+\left(\bar{x}-x_{2}\right)^{2}+\ldots+\left(\bar{x}-x_{n}\right)^{2}}{n-1}} .
$$

У делу Резултати и дискусија приказани су и детаљно анализирани статистички подаци који се односе на број случајева, обим штете и штете по једном насталом случају од елементарних непогода у државним шумама Републике Србије у периоду од 2008. до 2017. године (Табела 4). Обим штете по једном насталом случају израчунава се на основу формуле: 


$$
\check{S} N S=\frac{\check{S} E N_{i}}{n_{i}},
$$

где је: $\check{S} \boldsymbol{N} \boldsymbol{S}$ - штета настала по једном случају од елементарних непогода; $\breve{\boldsymbol{S}} \boldsymbol{E} \boldsymbol{N}_{i}-$ укупна штета од елементарних непогода у анализираној години; $\boldsymbol{n}_{\boldsymbol{i}}-$ укупан број евидентираних случајева штете у анализираној години.

У циљу сагледавања утицаја посматраних климатских елемената на број случајева, обим штете и на штете по једном насталом случају од елементарних непогода извршена је компаративна анализа трендова линија постојећих статистичких података за сваки климатски елемент понаособ. Ради процене утицаја посматраних климатских елемената анализирани период је рашчлањен на два најмање временска периода од по пет година, од 2008. до 2012. и од 2013. до 2017. године (Табела 5).

Добијени резултати у раду приказани су графички, применом кружних и линијских графикона.

У делу Резултати и дискусија посебно су издвојени и анализирани резултати који се односе на:

- утицај температуре, падавина и релативне влажности ваздуха на број случајева и обим штете од елементарних непогода у државним шумама Републике Србије;

- утицај температуре, падавина и релативне влажности ваздуха на штете по једном случају од елементарних непогода у државним шумама Републике Србије;

- компаративну анализу утицаја температуре, падавина и влажности ваздуха у периоду 2008-2012. и 2013-2017. године на број случајева, обим штете и штете по једном случају од елементарних непогода у државним шумама Републике Србије.

\section{РЕЗУЛТАТИ И ДИСКУСИЈА}

Обрадом прикупљених података са свих доступних метеоролошких станица у Републици Србији и применом формуле (1) добијене су средње годишње вредности истраживаних климатских елемената за период од 2008. до 2017. године (Табела 1). 
Табела 1. Средња годишња темература ваздуха (T), средња годишња сума падавина (Р) и средња годишња релативна влажност ваздуха (r) у Републици Србији у периоду 2008-2017.

\begin{tabular}{cccc}
\hline Година & $\mathrm{T}\left[{ }^{\circ} \mathrm{C}\right]$ & $\mathrm{P}[\mathrm{mm}]$ & $\mathrm{r}[\%]$ \\
\hline 2008. & 11,6 & 631,8 & 73,2 \\
2009. & 11,4 & 801,3 & 74,7 \\
2010. & 11,0 & 869,3 & 76,9 \\
2011. & 10,9 & 474,7 & 72,5 \\
2012. & 11,6 & 628,2 & 69,7 \\
2013. & 11,7 & 673,9 & 73,6 \\
2014. & 11,8 & 1024,0 & 78,0 \\
2015. & 11,8 & 690,6 & 74,0 \\
2016. & 11,3 & 873,4 & 75,6 \\
2017. & 11,5 & 636,8 & 72,1 \\
\hline Просек & 11,4 & 730,4 & 74,0 \\
Мин. & 10,9 & 474,7 & 69,7 \\
Макс. & 11,8 & 1024,0 & 78,0 \\
$s$ & 0,3 & 159,9 & 2,4 \\
\hline Извор: Метеоролошки годишњак 1- климатолошки подаци, \\
за период од 2008. до 2017. године (прорачун аутора)
\end{tabular}

Анализом података приказаних у Табели 1 , уочава се следеће:

- Средња годишња температура ваздуха у посматраном периоду кретала се у опсегу од $10,9^{\circ} \mathrm{C}$ у 2011. години до $11,8^{\circ} \mathrm{C}$ у 2014 . години. Средња годишња температура ваздуха за период 2008-2017. година износила је $11,4^{\circ} \mathrm{C}$, док је вредност средњег квадратног одступања $s= \pm 0,3^{\circ} \mathrm{C}$.

- Средња годишња сума падавина кретала се у опсегу од $474,7 \mathrm{~mm}$ у 2011. години до $1024 \mathrm{~mm}$ у 2014. години. Средња годишња сума падавина у периоду 2008-2017. износила је 730,4 mm, а док вредност средњег квадратног одступања $s= \pm 159,9 \mathrm{~mm}$.

- Средња годишња релативна влажност ваздуха кретала се у опсегу од $69,7 \%$ у 2012 . години до $78 \%$ у 2014. години. Средња годишња релативна влажност ваздуха за период 2008-2017. износила је 74\%, док вредност средњег квадратног одступања износи $s= \pm 2,4 \%$.

- Минималне вредности за температуру и падавине биле су у 2011. години, док су максималне вредности за сва три посматрана климатска елемента забележана током 2014. године. Ово значи да је 2014. година, по питању максималних вредности, била најекстремнија година у посматраном десетогодишњем периоду.

Обрађени и прикупљени подаци из билтена Шумарство у Peпублици Србији за период од 2008. до 2017. године (Републички завод за статистику, 2008-2017a), који се односе на штете у државним 
шумама према узроцима угрожавања и њиховом учешћу у укупним штетама и укупне штете у државним шумама, приказани су у Табели 2.

Табела 2. Штете у државним шумама према узроцима угрожавања y Републищи Србије у периоду 2008-2017. [y $\left.\mathrm{m}^{3}\right]$

\begin{tabular}{|c|c|c|c|c|c|c|c|}
\hline Година & $\begin{array}{l}\text { Штете } \\
\text { од } \\
\text { човека }\end{array}$ & $\begin{array}{c}\text { Штете } \\
\text { од } \\
\text { инсеката }\end{array}$ & $\begin{array}{c}\text { Штете од } \\
\text { дивљачи и } \\
\text { домаћих } \\
\text { животиња }\end{array}$ & $\begin{array}{c}\text { Штете од } \\
\text { природних } \\
\text { непогода }\end{array}$ & $\begin{array}{l}\text { Штете од } \\
\text { биљних } \\
\text { болести }\end{array}$ & $\begin{array}{c}\text { Штете од } \\
\text { пожара }\end{array}$ & $\begin{array}{c}\text { Укупне } \\
\text { штете у } \\
\text { државним } \\
\text { шумама }\end{array}$ \\
\hline 2008. & 22.229 & 3877 & 0 & 15.706 & 4611 & 5996 & 52.419 \\
\hline 2009. & 14.090 & 3021 & 0 & 19.937 & 8313 & 1897 & 47.258 \\
\hline 2010. & 13.881 & 4070 & 874 & 14.902 & 5093 & 16 & 38.836 \\
\hline 2011. & 28.285 & 3281 & 0 & 8141 & 3358 & 21.740 & 64.805 \\
\hline 2012. & 27.590 & 2583 & 0 & 18.619 & 5765 & 30.377 & 84.934 \\
\hline 2013. & 17.859 & 13.056 & 0 & 29.960 & 17.556 & 7178 & 85.609 \\
\hline 2014. & 26.524 & 29.861 & 0 & 41.107 & 14.769 & 9606 & 121.867 \\
\hline 2015. & 24.393 & 32.680 & 0 & 116.431 & 13.218 & 2479 & 189.201 \\
\hline 2016. & 21.760 & 40.520 & 0 & 86.826 & 37.249 & 36.600 & 222.955 \\
\hline 2017. & 26.327 & 27.303 & 0 & 44.074 & 17.504 & 6065 & 121.273 \\
\hline Укупно & 222.938 & 160.252 & 874 & 395.703 & 127.436 & 121.954 & 1.029 .157 \\
\hline$\%$ & 21,66 & 15,57 & 0,08 & 38,45 & 12,38 & 11,85 & 100,00 \\
\hline
\end{tabular}

Извор: Билтен Шумарство у Републици Србији, за период од 2008. до 2017. године (прорачун аутора)

Представљени подаци показују значајно учешће штете од природних непогода у државним шумама, које износи $38,45 \%$ од укупне штете (График 1). Ова вредност представља скоро $2 / 5$ од укупних штета које су евидентиране у државним шумама у Републици Србији у периоду од 2008. до 2017. године. На другом месту по учешћу узрока угрожавања јесу штете од човека $-21,66 \%$. Најмање учешће у анализираном периоду имале су штете од дивљачи и домаћих животиња $0,08 \%$.

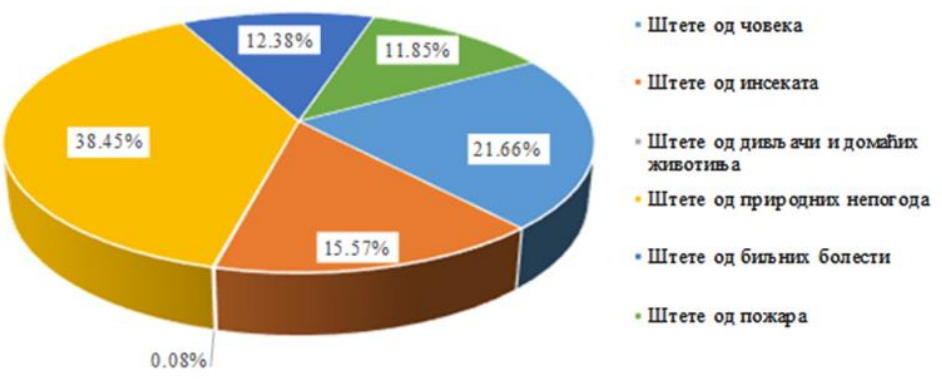

График 1. Штете према учешћу фактора угрожавања у проиентима у укупним штетама у државним шумама

Републике Србије у периоду 2008-2017.

Извор: Билтен Шумарство у Републици Србији, за период од 2008. до 2017. године (прорачун аутора) 
Груписањем података из Табеле 2, а који се односе на штете од елементарних непогода (штете од инсеката, природних непогода, биљних болести и пожара) по годинама у периоду од 2008. до 2017. године и применом формуле (3) добијени резултати о њиховом учешћу у укупним штетама у државним шумама у Републици Србији приказани су у Табели 3 .

Табела 3. Учешће штете од елементарних непогода у укупним итетама у државним шумама Републике Србије у периоду 2008-2017.

\begin{tabular}{cccc}
\hline Година & $\begin{array}{c}\text { Укупне штете } \\
\text { у државним шумама }\left[\mathrm{m}^{3}\right]\end{array}$ & $\begin{array}{c}\text { Штете од елементарних непогода у } \\
\text { државним шумама }\left[\mathrm{m}^{3}\right]\end{array}$ \\
\hline 2008. & 52.419 & 30.190 & 57,59 \\
2009. & 47.258 & 33.168 & 70,18 \\
2010. & 38.836 & 24.081 & 62,01 \\
2011. & 64.805 & 36.520 & 56,35 \\
2012. & 84.934 & 57.344 & 67,52 \\
2013. & 85.609 & 67.750 & 79,14 \\
2014. & 121.867 & 95.343 & 78,24 \\
2015. & 189.201 & 164.808 & 87,11 \\
2016. & 222.955 & 201.195 & 90,24 \\
2017. & 121.273 & 94.946 & 78,29 \\
\hline Укупно & 1.029 .157 & 805.345 & 78,25 \\
\hline
\end{tabular}

Извор: Билтен Шумарство у Републици Србији, за период од 2008. до 2017. године (прорачун аутора)

Анализом добијених резултата по годинама запажа се значајно варирање учешћа штете од елементарних непогода, која се кретала од $56,35 \%$, у 2011. години, па до 90,24\%, у 2016. години.

Ради добијања јасније слике о тренду учешћа штете од елементарних непогода у државним шумама за анализирани период у укупним штетама у Републици Србији добијени резултати приказани су графички (График 2).

Статистичком анализом података дошло се до следећих закључака:

- У осам случајева од укупно десет, штете од елементарних непогода у државним шумама имале су у укупним штетама учешће веће од $60 \%$;

- Учешће штете од елементарних непогода у укупним штетама у државним шумама Републике Србије за посматрани десетогодишњи период имало је просечну годишњу вредност од $78,25 \%$, што чини $4 / 5$ од укупно насталих штета;

- Линија тренда показује стопу повећања учешћа штете од елементарних непогода у укупним штетема у државним шумама Републике Србије од $3,21 \%$ годишње. 


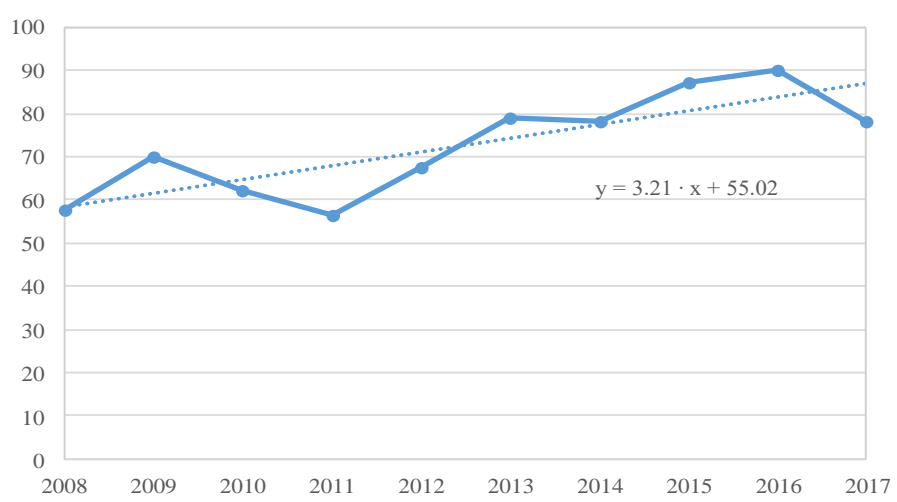

График 2. Тренд учешћа штете од елементарних непогода у укупним штетама у државним шумама у Републици Србији y периоду 2008-2017. [\%]

Извор: Билтен Шумарство у Републици Србији, за период од 2008. до 2017. године (прорачун аутора)

У Табели 4 приказане су по годинама штете у државним шумама настале по једном случају од елементарних непогода у Републици Србији у периоду 2008-2017. година. Резултати у последњој колони добијени су рачунањем према формули (4).

Табела 4. Штете у државним шумама од елементарних непогода по једном насталом случају у Републици Србији у периоду од 2008. до 2017. године

\begin{tabular}{cccc}
\hline Година & $\begin{array}{c}\text { Број случајева } \\
\text { штете }\end{array}$ & $\begin{array}{c}\text { Штете од } \\
\text { елементарних непогода } \\
{\left[\mathrm{m}^{3}\right]}\end{array}$ & $\begin{array}{c}\text { Штета настале по } \\
\text { једном случају } \\
{\left[\mathrm{m}^{3}\right]}\end{array}$ \\
\hline 2008. & 261 & 30.190 & 115,7 \\
2009. & 429 & 33.168 & 77,3 \\
2010. & 262 & 24.081 & 91,9 \\
2011. & 189 & 36.520 & 193,2 \\
2012. & 708 & 57.344 & 81,0 \\
2013. & 851 & 67.750 & 79,6 \\
2014. & 1131 & 95.343 & 84,3 \\
2015. & 881 & 164.808 & 187,1 \\
2016. & 899 & 201.195 & 223,8 \\
2017. & 1173 & 94.946 & 80,9 \\
\hline Укупно & 6784 & 805.345 & 118,71 \\
\hline Просек & 678,4 & $80.534,5$ & 718,71 \\
Мин. & 189 & 24.081 & 77,31 \\
Макс. & 1173 & 201.195 & 223,80 \\
$s$ & 6784 & 805.345 & 56,96 \\
\hline
\end{tabular}

Извор: Билтен Шумарство у Републици Србији, за период од 2008. до 2017. године (прорачун аутора) 
У анализираном периоду од 2008. до 2017. године у државним шумама Републике Србије укупно је евидентирано 6784 случајева штете од елементарних непогода, што је просечно годишње износило 678,4 случајева. Односно, сваког дана забележено је приближно два случаја $(1,86)$ штете. Даљом анализом, добијени резултати показују да се обим штете по једном случају кретао у опсегу од $77,31 \mathrm{~m}^{3}$ у 2009 , па до $223,80 \mathrm{~m}^{3}$ у 2016 . години. Просечна годишња вредност обима штете по једном насталом случају у анализираном периоду износила je $118,71 \mathrm{~m}^{3}$, а средње квадратно одступање $s= \pm 56,96$.

Утииај температуре, падавина и релативне влажности ваздуха на број случајева и обим штете од елементарних непогода

удржавним шумама

У циљу извођења закључака, прикупљени и обрађени подаци компарацијом одабраних низова података приказани су линијским графиконима (График 3, 4, 5, 6, 7 и 8). Утицај средње годишње температуре ваздуха, средње годишње суме падавина и средње годишње релативне влажности ваздуха утврђен је у односу на:

- број случајева настале штете од елементарних непогода (графици 3,5 и 7) и

- обим настале штете од елементарних непогода (графици 4, 6 и 8$)$,

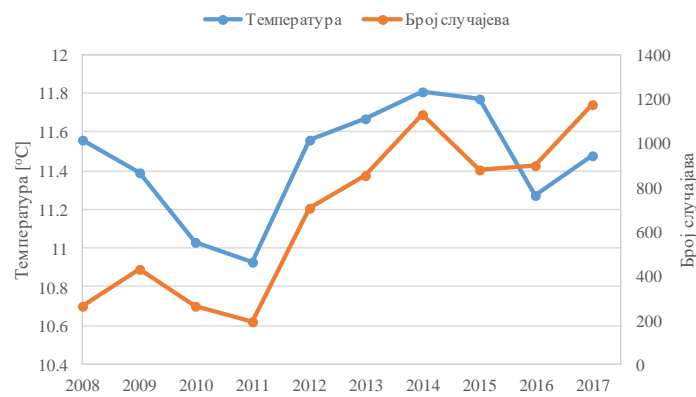

График 3. Утицај средње годишње температуре ваздуха на појаву броја случајева штете од елементарних непогода у државним шумама у Републици Србији у периоду 2008-2017. Извор: Према подацима из табела 1 и 4 


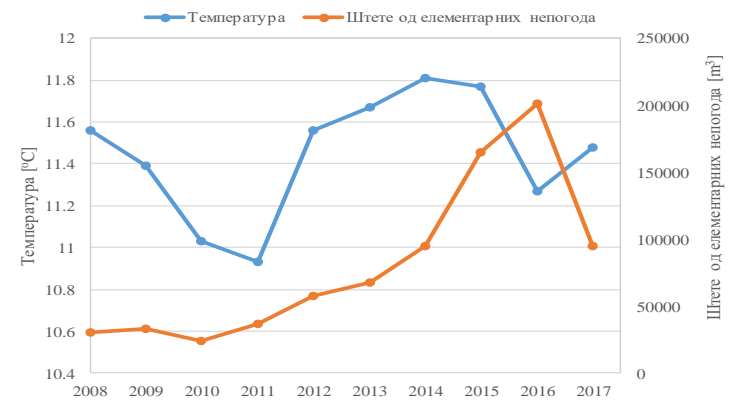

График 4. Утииај средње годишње температуре ваздуха на обим штете од елементарних непогода

у државним шумама у Републищи Србији у периоду 2008-2017. Извор: Према подацима из табела 1 и 4

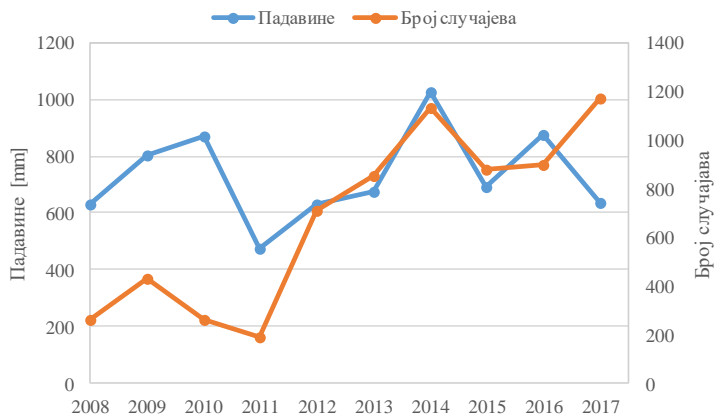

График 5. Утииај средње годииње суме падавина на појаву броја случајева штете од елементарних непогода у државним шумама у Републици Србији у периоду 2008-2017. Извор: Према подацима из табела 1 и 4

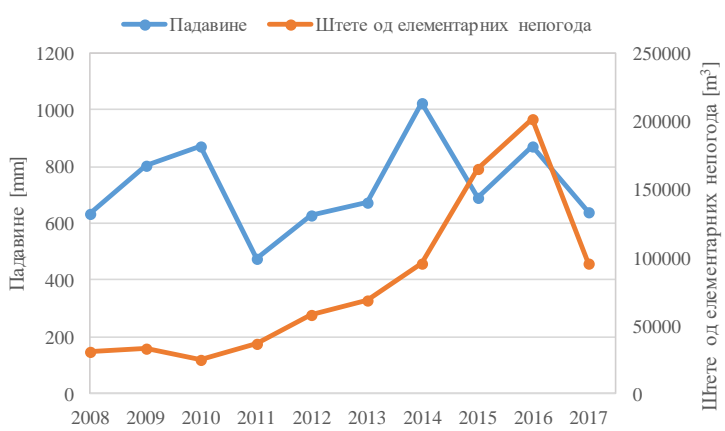

График 6. Утииај средње годишње суме падавина на обим штете од елементарних непогода у државним шумама у Републици Србији у периоду 2008-2017. Извор: Према подацима из табела 1 и 4 
Анализом линија трендова климатских елемената уочава се да је у 2011. години измерен минимум за два елемента од посматрана три елеманта. У тој години минималне вредности измерене су за средњу годишњу температуру ваздуха $10,9^{\circ} \mathrm{C}$ и за средњу годишњу суму падавина $474,7 \mathrm{~mm}$. Минимална вредност $69,7 \%$ за средњу годишњу релативну влажност ваздуха измерена је у 2012. години. Што се тиче максималних вредности климатских елемената, оне су измерене у 2014. години, и то за: средњу годишњу температуру ваздуха $11,8^{\circ} \mathrm{C}$, средњу годишњу суму падавина $1024 \mathrm{~mm}$ и средњу годишњу релативну влажност ваздуха $78 \%$.

Уколико анализирамо тренд кретања броја случајева штете од елементарних непогода у државним шумама Републике Србије у периоду од 2008. до 2017. године, запажа се да је у 2011. години евидентиран минималан број случајева (189) појава ове штете. Максималан број случајева појава штете од елементарних непогода евидентиран у 2017. години (1173 случаја). Просечан број случајева настале штете од елементарних непогода у државним шумама Републике Србије у анализираном периоду је 678 , а средње квадратно одступање $s= \pm 368$.

Тренд кретања штете у државним шумама од елементарних непогода у Републици Србији имао је минималну вредност од $24.081 \mathrm{~m}^{3}$ посечене запремине дрвета у 2010. години. У 2016. години евидентиран је максимум посечене запремине дрвета, који је износио $201.195 \mathrm{~m}^{3}$. Просечна штета у анализираном периоду износила је $80.534,5 \mathrm{~m}^{3}$ посечене запремине дрвета у државним шумама Републике Србије, а средње квадратно одступање износи $s= \pm 63.699 \mathrm{~m}^{3}$.

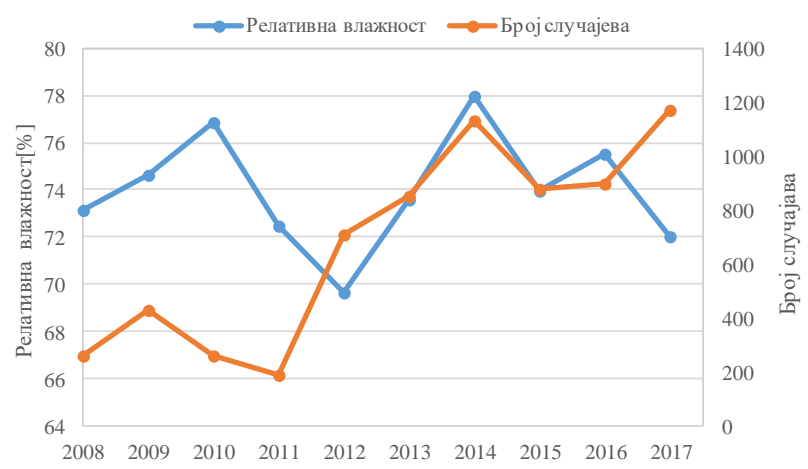

График 7. Утииај средње годишње релативне влажности ваздуха на појаву броја случајева штете од елементарних непогода у државним шумама у Републищи Србији у периоду 2008-2017. Извор: Према подацима из табела 1 и 4 


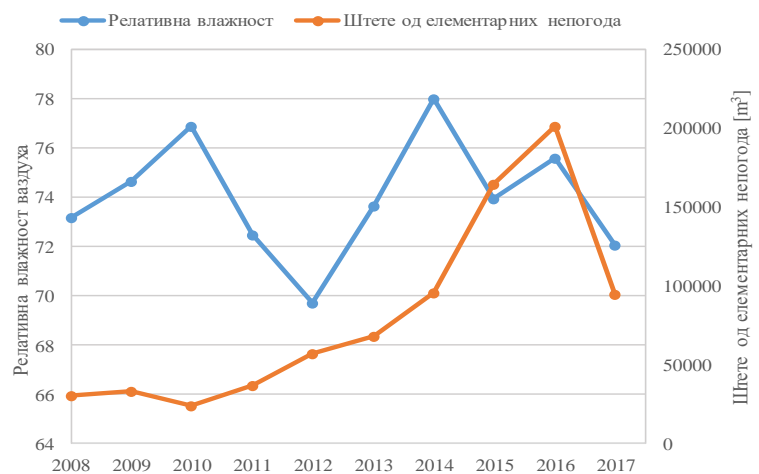

График 8. Утииај средње годишње релативне влажности ваздуха на обим штете од елементарних непогода у државним шумама у

Републици Србији у периоду 2008-2017.

Извор: Према подацима из табела 1 и 4

Утицај температуре, падавина и релативне влажности ваздуха на штете по једном случају од елементарних непогода у државним шумама Републике Србије

У овом делу рада анализирани су трендови линија утицаја средње годишње температуре ваздуха (График 9), средње годишње суме падавина (График 10) и средње годишње релативне влажности ваздуха (График 11) на обим штете по једном случају од елементарних непогода у државним шумама у Републици Србији у периоду од 2008. до 2017. године (Табела 4).

Анализом трендова кретања средње годишње температуре ваздуха и штете по једном случају настале од елементарних непогода очигледно је да не постоји директан утицај промене температуре на обим штете. Са графика се види да је за најнижу измерену средњу годишњу температуру ваздуха, која износи $10,9^{\circ} \mathrm{C}$, евидентирана приближно максимална вредност штете по једном насталом случају, која је износила $193,23 \mathrm{~m}^{3}$. Максимална вредност од $223,80 \mathrm{~m}^{3}$ посечене запремине дрвета по једном случају евидентирана је у 2016. години, у којој је средња годишња температура ваздуха имала вредност од $11,3^{\circ} \mathrm{C}$.

Средња годишња вредност температуре од $11,6^{\circ} \mathrm{C}$ у 2008 . и 2012. години проузроковала је различите обиме штете настале по једном случају од 115,67 , односно $80,99 \mathrm{~m}^{3}$, посечене дрвне масе, тако да је за исту вредност температуре ваздуха дошло до смањења штете за $34 \mathrm{~m}^{3}$ у 2012. години у односу на 2008. годину. Минимална штета по једном насталом случају од елементарних непогода од $77,31 \mathrm{~m}^{3}$ забележена је у 2009. години, када је средња годишња температура ваздуха имала вредност $11,4^{\circ} \mathrm{C}$. 


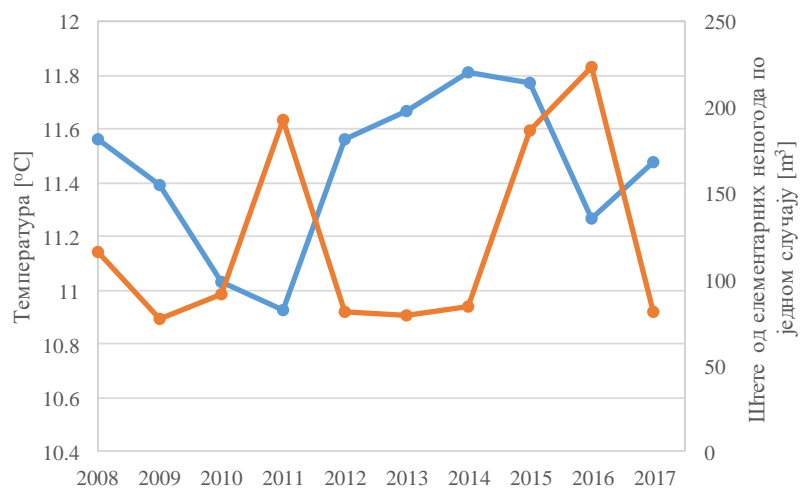

График 9. Утииај средње годишње температуре ваздуха на штете по једном случају од елементарних непогода у државним шумама у Републици Србији у периоду 2008-2017. Извор: Према подацима из табела 1 и 4

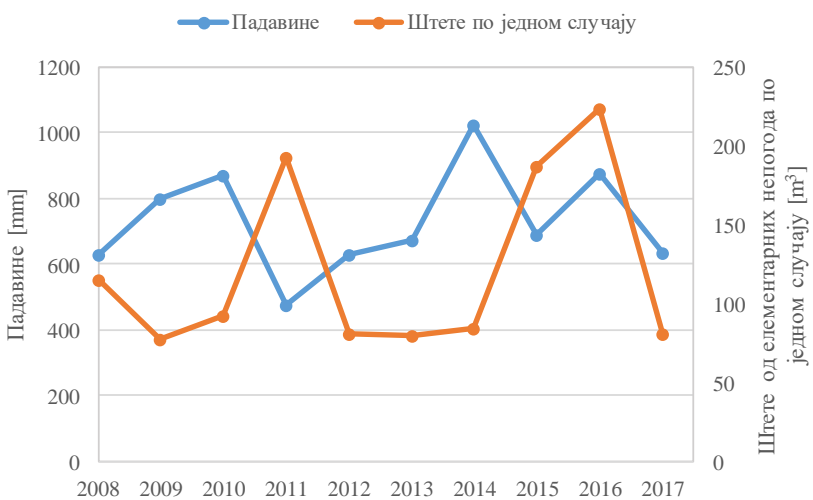

График 10. Утииај средње годишње суме падавина на штете по једном случају од елементарних непогода у државним шумама у Републищи Србији у периоду 2008-2017. Извор: Према подацима из табела 1 и 4

Такође, обим настале штете испод $80 \mathrm{~m}^{3}$ забележен је и у 2013 . години, када је штета била $79,61 \mathrm{~m}^{3}$ посечене запремине дрвета, а вредност средње годишње температуре ваздуха износила је $11,7^{\circ} \mathrm{C}$. Упоређујући обим насталих штета у ове две године, може се закључити да је за промену температуре од $+0,3^{\circ} \mathrm{C}$ дошло до повећања обима штете за $2,3 \mathrm{~m}^{3}$ посечене запремине дрвета. Ова промена температуре једнака је добијеној вредности $s= \pm 0,3^{\circ} \mathrm{C}$.

Уколико се анализирају трендови кретања средње годишње суме падавина и појединачне штете од елементарних непогода, као и 
код претходног климатског елемента, ни код овог се не уочава постојање директног утицаја на обим штете. И у овом случају имамо ситуацију да минимална вредност климатског елемента проузрокује приближно максималан обим настале штете по једном случају. А то значи да је минимална средња годишња сума падавина од 474,7 mm проузроковала штету по једном случају од 193,23 $\mathrm{m}^{3}$ посечене запремине дрвета. Максимална средња годишња сума падавина у 2014. години од $1024 \mathrm{~mm}$ проузроковала је штету по једном случају од $84,30 \mathrm{~m}^{3}$. Са друге стране, максимална штета од $223,80 \mathrm{~m}^{3}$ у овом периоду настала је у 2016. години, када је средња годишња сума падавина износила $873,4 \mathrm{~mm}$.

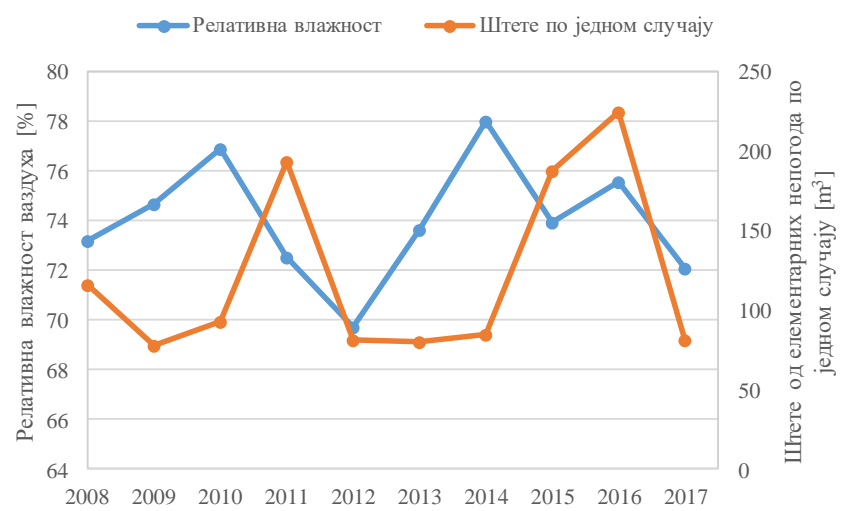

График 11. Утииај средње годишње релативне влажности ваздуха на штете по једном случају од елементарних непогода у државним шумама у Републици Србији у периоду 2008-2017. Извор: Према подацима из табела 1 и 4

У анализираном периоду динамика промене количине средње годишње релативне влажности ваздуха и промене обима штете по једном случају настале од елементарних непогода у државним шумама, такође, као и у претходна два случаја, не показује директан утицај овог климатског елемента на обим штете. За вредност минималне средње годишње релативне влажности ваздуха од 69,7\%, евидентиране у 2012. години, обим штете по једном насталом случају износио je $80,99 \mathrm{~m}^{3}$ посечене запремине дрвета. Приближна вредност настале штете по једном случају евидентирана је у последњој анализираној години, када је посечена запремина дрвета износила 80,94 m³ , а притом је вредност за средњу годишњу влажност ваздуха износила $72,1 \%$, што је за $2,38 \%$ више у односу на минималну евидентирану вредност. Ово повећање је приближно вредности за средње квадратно одступање од средње вредности $s= \pm 2,4174 \%$. Такође, и за овај климатски елемент, као и за претходна два, уочава се појава да су у 
годинама са нижим вредностима за релативну влажност ваздуха евидентирана знатно већа оштећења од елементарних непогода по једном случају и, супротно, да је за вредности изнад просечних евидентирана знатно мања количина оштећене запремине дрвета по једном случају. Изузетак од ове констатације показују подаци евидентирани у 2016. години, када је забележена највећа количина посечене запремине дрвета, 223,80 $\mathrm{m}^{3}$ по једном случају, при нешто вишој вредности релативне влажности ваздуха од просечне вредности у анализираном периоду 75,6> $74 \mathrm{~mm}$.

Компаративна анализа утицаја температуре, падавина и влажности ваздуха у периоду 2008-2012. и 2013-2017. године на

број случајева, обим штете и штете по једном случају од елементарних непогода у државним шумама Републике Србије

Рашчлањењем анализираног периода на два мања, од по пет година - од 2008. до 2012. и од 2013. до 2017. године - добијени резултати приказани су у Табели 5.

Табела 5. Упоредни приказ температуре (T), падавина (P), релативне влажности ваздуха (r), број случајева, штете од елементарних непогода и штете по једном случају

\begin{tabular}{ccccccc}
\hline Период & $\mathrm{T}\left[{ }^{\circ} \mathrm{C}\right]$ & $\mathrm{P}[\mathrm{mm}]$ & $\mathrm{r}[\%]$ & $\begin{array}{c}\text { Број } \\
\text { случајева }\end{array}$ & $\begin{array}{c}\text { Штете од } \\
\text { елементарних } \\
\text { непогода }\left[\mathrm{m}^{3}\right]\end{array}$ & $\begin{array}{c}\text { Штете по } \\
\text { једном случају } \\
{\left[\mathrm{m}^{3}\right]}\end{array}$ \\
\hline $2008-2012$. & 11,3 & 681,1 & 73,4 & 370 & 36.261 & 98,05 \\
$2013-2017$. & 11,6 & 779,7 & 74,6 & 987 & 124.808 & 126,45 \\
$2008-2017$. & 11,4 & 730,4 & 74,0 & 678 & 80.534 & 121,48 \\
\hline
\end{tabular}

Извор: Према подацима Табела 1. и 4.

На основу добијених података, уочава се пораст температуре од $+0,2^{\circ} \mathrm{C}$ у другом петогодишњем периоду у односу на десетогодишњи просек, који износи $11,4^{\circ} \mathrm{C}$, односно $+0,3^{\circ} \mathrm{C}$, у односу на период 2008-2012. Сума падавина такође је у другом периоду имала већу вредност за +49,4 mm у односу на просек у анализираном периоду, који износи $730,4 \mathrm{~mm}$, односно за $+98,7 \mathrm{~mm}$ у односу на први период. Релативна влажност ваздуха бележи повећање за $+0,6 \%$ у односу на просечну вредност у периоду 2008-2017, који износи 74\%, односно $1,25 \%$ у односу на добијену вредност за петогодиши период 2008-2012.

У периоду 2013-2017. дошло је и до повећања вредности које се односе на број случајева, обим штете и штете по једном случају од елементарних непогода у државним шумама Републике Србије у односу на просечне вредности у анализираном десетогодишњем пе- 
риоду и у односу на период 2008-2012. Број случајева повећао се за 1,5 пута у односу на просечну вредност, односно за 2,67 пута у односу на број случајева који су евидентирани у периоду 2008-2012. Штете од елементарних непогода у периоду од 2013. до 2017. године биле су 3,44 пута веће у односу на период 2008-2012, односно за 1,55 пута у односу на период 2008-2017, када је просечна вредност била $80.534,5 \mathrm{~m}^{3}$ посечене запремине дрвета. Вредност штете од елементарних непогода по једном случају у периоду 2013-2017. била је за 1,29 пута већа од настале штете по једном случају у периоду 2008-2012, односно бележи повећање од 4\% у односу на просечну вредност у периоду 2008-2017.

\section{ЗАКЉУЧАК}

На основу спроведене анализе, може се закључити да је у седам случајева од укупно 10 анализираних, постојала бар једна екстремна вредност у низу од шест истраживаних скупова података, а који се односе на средњу годишњу температуру ваздуха, средњу годишњу суму падавина, средњу годишњу релативну влажност ваздуха, број случајева настале штете, обим штете и штете по једном насталом случају од елементарних непогода у државним шумама Републике Србије у периоду од 2008. до 2017. године.

Минималне вредности средње годишње температуре ваздуха од $T=10,9^{\circ} \mathrm{C}$ и средње годишње суме падавина $P=474,7 \mathrm{~mm}$ биле су у 2011. години, док је минимум средње годишње релативне влажности ваздуха од $r=69,7 \%$ био у 2012. години.

У анализираном периоду, година 2014. забележена је као година са измереним максималним вредностима свих посматраних климатских елемената: средња годишња температура ваздуха од $T=$ $11,8^{\circ} \mathrm{C}$, средња годишња сума падавина од $P=1024 \mathrm{~mm}$ и вредност средње годишње релативне влажности ваздуха од $r=78 \%$.

Што се тиче минималних и максималних вредности које се односе на број случајева насталих штета, обим штете и штете по једном насталом случају од елементарних непогода у државним шумама у Републици Србији, може се закључити да је:

- најмање: а) случајева настале штете евидентирано у 2011. години (189 случајева), б) посечене запремине дрвета било је у 2010 . години $\left(24.081 \mathrm{~m}^{3}\right)$ и в) штете по једном случају у 2009. години, када је посечено $77,31 \mathrm{~m}^{3}$ запремине дрвета;

- највише: а) случајева настале штете евидентирано је у 2017. години (1173 случаја), б) посечене запремине дрвета било је у 2016. години $\left(201.195 \mathrm{~m}^{3}\right)$ и штете по једном случају, када је посечено $223,80 \mathrm{~m}^{3}$ запремине дрвета. 
Рашчлањењем анализираног периода на два мања периода од по пет година, дошло се до следећих чињеница: температура је са $11,3^{\circ} \mathrm{C}$ у првом (2008-2012) порасла на $11,6^{\circ} \mathrm{C}$ у другом петогодишњем периоду (2013-2008), падавине су се повећале са 681,1 на $779,7 \mathrm{~mm}$, а влажност ваздуха се повећала са 73,4 на 74,6\%. Повећање петогодишњих просечних вредности за ове климатске елементе утицало је и на повећање броја случајева штете од 370 на 987 од елементарних непогода, односно штете изражене у посеченој запремини дрвета повећале су се од 36.261 на $124.808 \mathrm{~m}^{3}$ и, такође, дошло је до поваћања штете по једном случају од 98 на $126 \mathrm{~m}^{3}$.

На основу трендова вредности за средње годишње температуре ваздуха, средње годишње суме падавина и средње годишње релативне влажности ваздуха, утврђена је нелинеарна зависност промене ових вредности у односу на број случајева штете, обим штете и штете по једном случају, па се може рећи да су оне последица случајности, што значи да број случајева и обим штете од елементарних непогода зависе и од многих других фактора. Осим климатских елемената, од којих треба додати максималну и минималну температуру ваздуха, максималну и минималну количину падавина, облачност, влажност ваздуха и др., штете у шумама зависе и од многобројних других фактора (надморска висина, рељеф, месец, годишње доба и др.).

У анализираном периоду од 2008. до 2017. године, дошло је до смањења учешћа државних шума за $10 \%$ у односу на укупну површину под шумама и шумским земљиштем у Републици Србији. Наиме, у 2008. години под државним шумама се налазило 53\% површине под шумама и шумским земљиштем Републике Србије, а док је 2017. године овај проценат износио $43 \%$. Квантитативно опадање површина и процентуалног учешћа државних шума и шумског земљишта последица је враћања ове категорије земљишта бившим власницима. Из тог разлога, потребно је допунити истраживање новим подацима који се односе на приватне шуме. Међутим, то ће бити могуће једино ако се промени методологија евидентирања насталих штета у Републици Србији. За сада се не евидентирају штете настале у шумама у приватном власништву, сем за штете од пожара. Сматрамо да би ова истраживања дала релевантније резултате анализом података за дуже временске периоде, нпр. 30 или пак 50 година. Такође, свеобухватније сагледавање утицаја истраживаних климатских елемената на обим штете у шумским састојинама од елементарних непогода и доношење веродостојнијих закључака подразумева истраживање на једном одређеном локалитету.

У оквиру дискусије нису извршена упоређивања добијених резултата истраживања јер у доступној литератури не постоје подаци за ову проблематику. Већина аутора сагледава само утицај једног факто- 
ра угрожавања шума, нпр. штете у шумама од инсеката, од биљних болести, од природних непогода и од пожара, и најчешће само за један локалитет или регион. Такође, у циљу добијања квалитетнијих резултата, потребно је, поред одговарајућих статистичких метода, извршити и избор софтвера за симулацију климатских промена попут регионалног климатског модела који би обезбедио већу ефикасност будућих истраживања у овој области.

\section{ЛИТЕРАТУРА}

Andrasko, K. (1990). Global warming and forests: An overview of current knowledge. Unasylva - No. 163 - Forestry and environment, Vol. 41 - 1990/4, pp. 3-11.

Банковић, С., Медаревић, М., Пантић, Д., \& Петровић, Н. (2009). Национална инвентура шума Републике Србије [National forest inventory of the Republic of Serbia] - Шумски фонд Републике Србије. Министарство пољопривреде, шумарства и водопривреде - Управа за шуме, Београд.

Botkin, D. B., Nisbet, R. A., Simpson, L. G. (1992). Forests and Global Climate Change. In: S. K. Majumdar, L. S. Kalkstein, B. M. Yarnal, E. W. Miller, and L. M. Rosenfeld (eds.): Global Climate Change: Implications, Challenges and Mitigation Measures, Philadelphia, Pennsylvania Academy of Sciences, Chapter 19, pp. 274-290.

Брашанац - Босанац, Љ. (2013). Шумски екосистеми Србије у функиији заштите животне средине од негативог утицаја климатских промена [Forest ecosystems of Serbia in the function of environmental protection from negative climate changes impact]. Докторска дисертација. Универзитет у Београду. Географски факултет. Београд.

Даниловић, М. (2016). Избор метода и система рада при коришћењу случајних приноса насталих као последица сушења шума, ледолома и ледоизвала на nодручју Србије [The choice of methods and systems of work when using random yields resulting from forest dieback, ice breaks and icethrows in Serbia]. Научноистраживачки пројекат (коначни извештај). Универзитет у Београду. Шумарски факултет. Катедра за искоришћавање шума. Београд.

Dragović, N. i sar. (ed.) (2017). Upravljanje prirodnim resursima u Jugoistočnoj Evropi: Šume, zemljište i vode [Natural Resources Management in South East Europe: Forests, Land and Water]. GIZ Skopje. str. 263.

http://seerural.org/wp-content/uploads/2018/02/NRM-Report-Serbian-Final.pdf

Đorđević, S. (ed.) (2015). Klimatske promene i prirodni hazard [Climate change and natural hazards]. Omladinsko udruženje „Naša Ljubovija”, Unija ekologa Uneko, Eko Drina Mali Zvornik. „Plus Kopi” Šabac.

Forest Europe (2015). State of Europe's Forests 2015; 7th Ministerial Conference on the Protection of Forests in Europe. https://www.foresteurope.org/docs/fullsoef2015. pdf

Група аутора. (2016). Истраживања социо-економских аспеката ризика услед климатских промена у шумским подручјима [Research on the socio-economic aspects of risks due to climate change in forest areas]. Универзитет у Београду. Шумарски факултет. Катедра за бујице и ерозију и Катедра Економике и организације шумарства. Пројекат. Београд. https://www.paragraf.rs/propisi/ zakon-o-smanjenju-rizika-od-katastrofa-i-upravljanju-vanrednim-situacijama.html

Илић Крстић, И. (2016). Социјално-еколошка безбедност, одрживи развој и квалитет живота [Socio-ecological Safety, Sustainable Development and 
Quality of Life]. Докторска дисертација. Универзитет у Нишу. Факултет заштите на раду у Нишу. Ниш. стр. 311.

Илић Крстић, И. (2018). Еколошка безбедност у пограничју: студија случаја [Ecological Safety at the border: a case study]. Монографија. Прометеј, Ниш. стр. 104.

IPCC, (2014). Climate Change 2014: Synthesis Report. Contribution of Working Groups I, II and III to the Fifth Assessment Report of the Intergovernmental Panel on Climate Change [Core Writing Team, R. K. Pachauri and L. A. Meyer (eds.)]. IPCC, Geneva, Switzerland, pp. 151.

Караџић, Д. (2007). Климатске промене и ьихов потенцијални утицај на проузроковаче болести шумског дрвећа и жбуња [Climate change and their potential effects on causes diseases of forest trees and shrubs], У: Кадовић, Р. \& Медаревић, М. (Ур.): Шуме и промене климе, Зборник радова (стр. 153-164), Министарство за пољопривреду, шумарство и водопривреду Републике Србије - Управа за шуме и Универзитет у Београду - Шумарски факултет, Београд.

Kovačić, Z. (1995). Analiza vremenskih serija [Time Series Analysis]. Univerzitet u Beogradu, Ekonomski fakultet. Beograd.

Mijović, A. (ed.) (2014). The Fifth National Report to the United Nations Convention on Biological Diversity. Republic of Serbia, Ministry of Agriculture.

Милутиновић, Б. (2018). Приручник за планирање прилагођавања на измењене климатске услове у локалним заједницама у Србији [Planning Guide for Climate Change Adaptation in Local Communities in Serbia]. Стална конференција градова и општина. Београд.

Mudelsee, M. (2014). Climate Time Series Analysis: Classical Statistical and Bootstrap Methods, 2nd ed. Springer, Cham, Switzerland. pp. 454.

Nonić, D., Stanišić, M., Nedeljković, J. \& Ranković, N. (2017). Cooperation in the climate change mitigation in forestry and nature protection at different levels of governance. Glasnik šumarskog fakulteta. Beograd. No 116: 99-140. Doi:/10.2298/GSF 1716099N

Perović, D. \& Radukić, S. (2015). Comparative analysis of sustainable development components for the republic of Serbia and neighbouring countries, Teme, g. XLI, br. 3, july - september, pp. 747-765. Doi: 10.22190/TEME1703747P

Петровић, Г., \& Грујовић, М. (2015). Економске штете од елементарних непогода у Србији и Шумадијском округу [The Economic Damage from Natural disasters in Sebia and Sumadija District]. Економски сигнали: пословни магазин, 10(2), 99-107.

Петровић, М. (2014). Ризик појам и класификација [Risk - Term and Classification], https://www.academia.edu/7183598, приступљено 27. априла 2019. године

Petz, B. (2007): Osnovne statističke metode za nematematičare [Basic Statistical Methods for Non-Mathematicians], VI izdanje, Udžbenici Sveučilišta u Zagrebu, Jastrebarsko: Naklada Slap, Zagreb.

Правилник о националној листи индикатора заштите животне средине [Rulebook on the National List of Indicators of Environmental Protection], „Службени гласник PC”, бр. 37/11. Службени гласник, Београд. (2011)

Ранковић, Н., Недељковић, Ј., Златић, М., Станишић, М. \& Нонић, Д. (2016). Кретање обима штета од природних непогода у шумама Србије и утицај температуре и падавина [Influence of temperature and precipitation on the extent of forest damages from natural hazards], Гласник Шумарског факултета 114 , Универзитет у Београду - Шумарски факултет, Београд. стр. 201-218 Doi: 10.2298/GSF1614201R 
Републички завод за статистику, Статистички годишњак Републике Србије [Statistical Yearbook of the Republic of Serbia], Београд. (2018a)

Републички завод за статистику. Билтен - Шумарство у Републици Србији [Bulletin - Forestry in the Republic of Serbia], за период 2008-2017. године (20082017a)

Републички хидрометеоролошки завод. Метеоролоски годисњак 1 - климатолоски подаци [Meteorological Yearbook 1 - Climatological Data], за период 20082017. године. (2008-2017б)

Шешић, Б. (1978). Основи методологије друштвених наука [Fundamentals of Social Science Methodology], друго издање, Научна књига, Београд.

Vuletić, D., Kauzlarić, Ž., Balenović, I. \& Krajter Ostoić, S. (2014). Assessment of forest damage in Croatia caused by Natural hazards in 2014. SEEFOR 5 (1): 65-79. $\mathrm{Http}: / /$ seefor.eu, pristupljeno 5. 10. 2018. godine

Wulff, S. (2011). Monitoring Forest Damege (Medods and Development in Sweden). Doctoral Thesis. Swedish University of Agricultural Sciences. Umeå.

Закон о смањењу ризика од катастрофа и управљању ванредним ситуацијама [Law on Disaster Risk Reduction and Emergency Management], „Службени гласник PC” бр. 87/18, приступљено, 17. маја 2019. године (2018б)

Закон о шумама [Forest Law], „Службени гласник PC” бр. 30/10, 93/12, 89/15 и 95/18, Службени гласник Републике Србије, Београд. (2010)

Živanović, S. (2012). Analysis of climate change elements to prediction of forest fires. Topla/Poplar No 189/190. pp. 163-170

Живановић, С., Ђорђевић, Г. \& Радаковић, Н. (2012). Утицај климатских елемената на ризик шума од пожара на подручју НП „Ђердап” [Influence of climatic elements on forest fire risk in the NP Đerdap]. „Шумарство” 3-4. Београд. стр. 175-184.

Живановић, С., Вукин, М. \& Кењевац, Б. (2019). Утицај временских прилика на појаву шумских пожара на подручју парка природе „Стара планина” током јула 2007. године [The impact of weather conditions on the occurrence of forest fire in „Stara Planina” Nature Park in July 2007], „Шумарство” 3-4. Београд. стр. $175-184$.

\title{
INFLUENCE OF TEMPERATURE, PRECIPITATION AND AIR HUMIDITY ON THE DAMAGE FROM NATURAL HAZARDS AND DISASTERS IN SERBIAN STATE FORESTS
}

\author{
Danijela Avramović, Dragan Spasić \\ University of Niš, Faculty of Occupational Safety, Niš, Serbia
}

\section{Summary}

In recent years there have been many examples of negative impacts of some climate elements on forest stands and forest land. In that view, the impact of average annual air temperature, average annual precipitation and average annual relative air humidity to number of incidence of damage, the scope of damage, and the damage per one disaster event from natural hazards and disasters is analyzed. The term of damage from natural hazards and disasters includes the data related to damages on state forest from insect activities, plant diseases, geophysical events and wildfires in Serbia, from 2008. to 2017. 
According to the analysis of collected data from measured values of three climate elements: average annual air temperature, average annual precipitation and average annual relative air humidity, there is the nonlinear trend of these element changes.

The average annual air temperatures for analysed period take values from 10.9 (min. in 2011.) to $11.80 \mathrm{C}$ ( $\max$. in 2014.). The average annual precipitation takes values from 474.7 (min. in 2011.) to $1024 \mathrm{~mm}$ (max. in 2014). The average annual relative air humidity takes values from 69.7 (min. in 2012.) to $78 \%$ (max. in 2014.).

The least number of damage cases is recorded in 2011. (189 cases). The least volume of wood was cut in 2010 (24081 m3). The minimal value of damage per one disaster event is noticed in 2009. when the value of cut wood volume was $77.31 \mathrm{~m} 3$.

The most damage cases are recorded in 2017. (1173 cases). The most volume of wood was cut in 2016. (201195 m3). The maximum value of damage per one disaster event is noticed in 2016. when the value of cut wood volume was $223,80 \mathrm{~m} 3$.

If we look at the analyzed period as two five year periods, there are the following facts: the temperature has risen from 11.3 (first period) to $11.6 \mathrm{oC}$ (second period), the precipitation has risen from 681.1 to $778 \mathrm{~mm}$, the air humidity has risen from 73.4 to $74.6 \%$. The growing values cause the increase number of damage cases from natural hazards and disasters from 370 to 987, the scope damage as cut wood volume from 36261 to $124808 \mathrm{~m} 3$ and the damage per one disaster event from 98 to $126 \mathrm{~m} 3$.

According to the trends of average annual air temperature, average annual precipitation and average annual relative air humidity the non linear dependence of value changes in relation of number of incidence of damage, the scope of damage, and the damage per one disaster event from natural hazards and disasters, so we can conclude that this is consequence of coincidence. That means the number of cases and scope damage depend of many factors. Beside climate factors like maximum and minimum air temperature, precipitation, cloudiness, air humidity, the damages in forests depend on numerous factors (altitude, relief, month, season). 